\title{
Does Knowledge Sharing Increase Innovation Capability? Answer from Indonesian Company
}

\author{
Dewiana Novitasari \\ Sekolah Tinggi Ilmu Ekonomi Insan Pembangunan, Indonesia
}

\begin{abstract}
Nowadays, there are a lot of innovations being discussed, conducted in a seminar, written, and explained in a small to a large classroom and also a meeting room. Innovation is related with the essentials of surviving in the middle of industrial era 4.0. Innovation is unable to be separated with the personal knowledge, in which both of them need a good and continuous management. This research aimed to measure the tacit influence and explicit knowledge towards innovation capability as well as answering research questions regarding the impact of knowledge sharing to improve innovation capability in the manufacturing industry. Data collection is done through a simple random sampling technique given to 610 employees in packaging industries in Indonesia. The questionnaire results that were given back and were valid have a number of 393 samples. Data processing was used SEM method with SmartPLS 3.0 software. The result of this research concluded that explicit and tacit knowledge have positive impact towards innovation capability. This new research proposed a model for building innovation capability in packaging industries through tacit and explicit knowledge transfer. This research could pave the way to improve readiness index to packaging industries in facing the era of industrial revolution 4.0.
\end{abstract}

Keywords: Explicit knowledge, innovation capability, tacit knowledge

\section{INTRODUCTION}

The new challenges that affect the presence and the continuity of packaging industries nowadays are a dramatic change that came from the industrial revolution 4.0. This industrial revolution requires human resources that are capable, agile, adaptive and responsive towards fast changes. Business organizations also need an environment that positively and conductively grows in competing in global market. Therefore, it cannot be denied that packaging industries need a synergy between the human resource and work environment that would give continuous improvements in innovation and performance. The point is in this economic knowledge era, there will be a presence of a society of knowledge that needs innovation and flexibility as the energy to survive from competition. As a result, strategic development in a company in the future is being in the improvement of knowledge resource that pave the way of innovation and fast growth.

To make sure that business organizations can be competitive and adaptive, the employees need to be taught and involved in building organization's performance. As a result, organizations should be formed into organizational learning. Organizational learning is highly significant for a company's organization that is operating in an environment having unexpected changes. Therefore, speed of the response regarding the changes is formed as an absolute requirement for winning the competition with competitors.

Individual's and organization's knowledge can be formed as an intellectual capital that would quickly become a new icon that describes the economic value as a company's organization. This is the new paradigm of a new industry 4.0. The dependency towards the traditional productive asset, such as raw materials, land, and other tangible assets are no longer a form of main infestation charity in the future. Productive and continuous assets in the future are intangible assets in a form of knowledge. This research seeks to understand the influence of learning process and individual knowledge sharing (tacit and explicit knowledge) of the employees of packaging industries in Indonesia that is related with the improvement of their innovation capability. 


\section{A. Research Hypothesis}

According to the formulation of problem, theoretical analysis, and conceptual framework of this research hypothesis is mentioned below:

H1: Explicit Knowledge is directly influencing the Innovative Capability

$\mathrm{H} 2$ : Tacit Knowledge is directly influencing the Innovative Capability

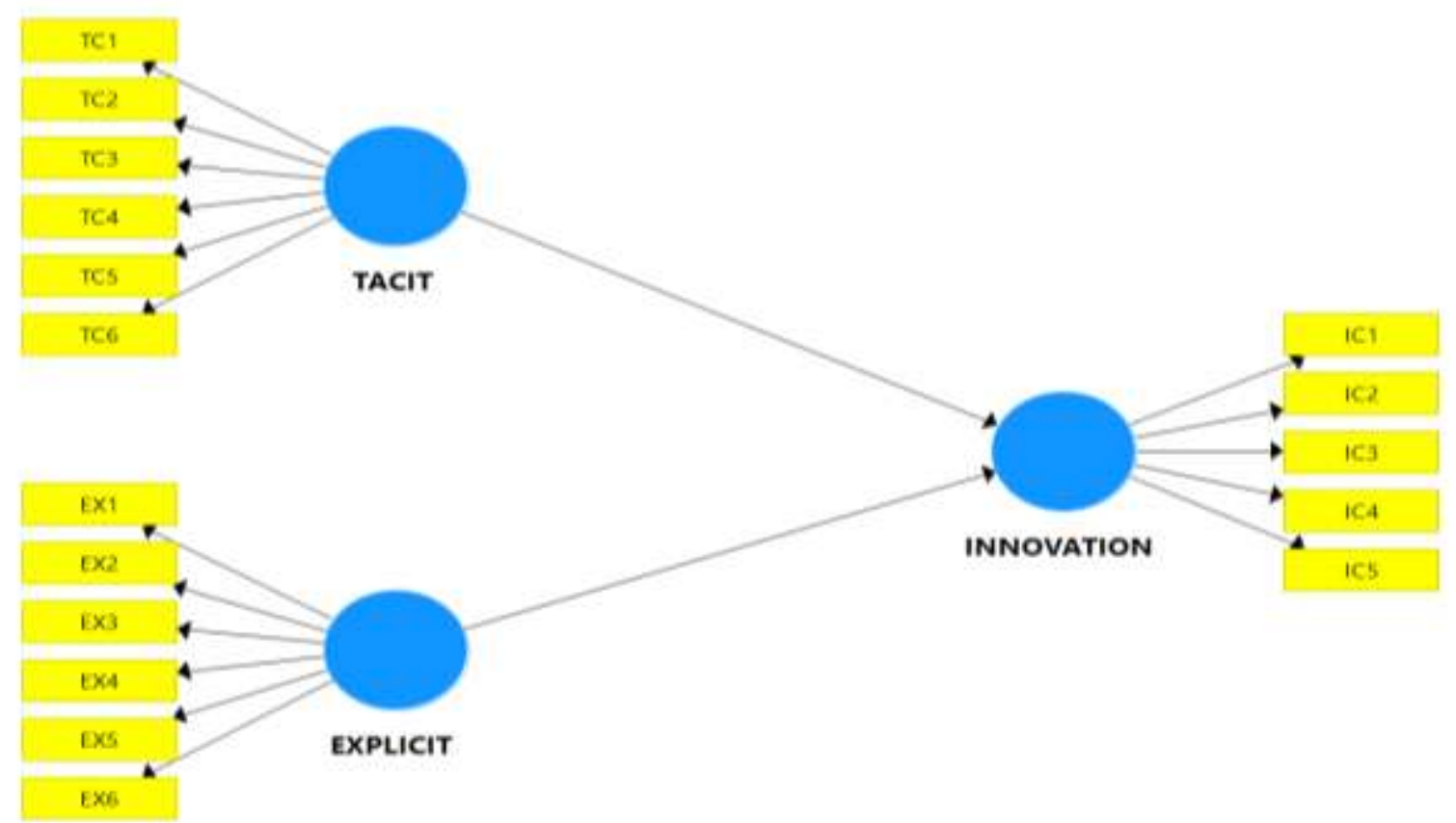

Figure 1. Research Model

\section{LITERATURE REVIEW AND HYPHOTESES}

\section{A. Tacit Knowledge}

Knowledge can be classified as two types covering: tacit knowledge and explicit knowledge (Polanyi, 1966). Tacit knowledge can be defined as a knowledge that is present in the human mind and tend to be personal (Chen et al, 2018; Holford, 2018; Khoshorour \& Gilaninia, 2018; Zebal, Ferdous \& Chambers, 2019; Agyemang \& Boateng, 2019; Perez-Fuillerat et al, 2018), it is hard to be formulated and is naturally divided (DeranEX, McLeod \& Schmidt, 2017; Wang \& Liu, 2019; Asher \& Popper, 2019) so in the transformation, it needs personal interaction (Lee, 2019). This tacit knowledge is present and rooted in an action or even other people's experiences including idealism, values, as well as emotions (Boske \& Osanloo, 2015; Kawamura, 2016; Hartley, 2018).

According to the definition, tacit knowledge can be categorized as personal knowledge or, in other words, a knowledge that is obtained from individuals. (Nonaka \& Toyama, 2015; Munoz et al, 2015; Stewart et al, 2017; Razmerita et al, 2016; Jaleel \& Verghis, 2015; Wang et al, 2016; Serna et al, 2017; Jou et al, 2016; Rothberg \& Erickson, 2017). Experience obtained by every employee is surely different from each other based on the situations and conditions that are unable to be predicted. Tacit knowledge is not easy to be articulated and converted into explicit knowledge Mohajan, 2016; Prasarnphanich et al, 2016; Addis, 2016; Cairo Battistutti, 2017; Zang et al, 2015; Spraggon \& Bodolica, 2017). Nevertheless, tacit knowledge can be empowered by the knowledge spiralization process or SECI Model (Li, Liu \& Zhou, 2018; Nonaka \& Hirose, 2018; Chatterjee et 
Every organization should utilize tacit knowledge of the employees by pushing them to share knowledge and keep learning. Companies like this could be more creative and innovation in being a leader in this industrial era 4.0. Organization could facilitate the process and use of tacit knowledge that are present outside the consciousness that is placed in the bottom of the mind by the approach of embedding and sharing (Ma et al, 2018; Ferreira et al, 2018; Borges et al, 2019; Ferraris et al, 2018; Guo et al, 2018; Tsai \& Hsu, 2019; SwierczEX, 2019; Cantwell \& Zaman, 2018).

\section{B. Explicit Knowledge}

Explicit knowledge is one of the types of knowledge that is easy to be documented and formed (Choi \& Lee, 2003; Sousa \& Rocha, 2019; Borrego et al, 2019; Wokcik et al, 2019; Cifariello, Ferragina \& Ponza, 2019; Che et al, 2018; Tang et al, 2016; Bashir \& Farooq, 2019; Attia \& Salama, 2018), easy to be articulated (Haamann \& Basten, 2018) and is usually a form of knowledge that sticks in the organization (Afsar, Masood \& Umrani, 2019). On the other side, explicit knowledge could be created, written, and transferred in between the organization's unit (Lombardi, 2019). Transfer of explicit knowledge in between employees is easier to be pushed by the mechanism and organization's culture that is conducive.

\section{Innovation Capability}

In this industrial era 4.0, innovation capability is needed as the organizational competitive advantage (Malik, 2019; Muscio \& Ciffolili, 2019; Durana et al, 2019; Lund \& Karlsen, 2019; Haseeb et al, 2019; Jakhar et al, 2018; Hamada, 2019), competitive strategy (Culot, Orzes \& Sartor, 2019), the key to face the industrial era 4.0 (Stachova et al, 2019), the part of management quality in the $21^{\text {st }}$ century (GunasEXaran, Sabramanian \& Ngai, 2019), provide many benefits to the business (Zambon et al, 2019; Parida, Sjodin \& Reim, 2019). Innovation capability is recognized as one of the most significant internal resource that could result to company's performance that excels (Zouaghi et al, 2018; Santoro et al, 2017; Castela et al, 2018; Ruiz-Torres et al, 2018; Huesig \& Endres, 2019).

\section{The Impact of Tacit and Explicit Knowledge towards Innovation Capability}

In this industrial era 4.0, it is marked by the tight competition, continuity stayed as a form of attention and significant problem. Innovation Capability can be formed as a pusher of business continuity. This performance is dependent by the culture of knowledge that is embedded in an organization. Knowledge includes tacit and explicit knowledge. There are a lot of researchers discussing innovation capability, which can be concluded that innovation is influenced by leadership (Samsir, 2018; Schuckert et al, 2018; Villaluz \& Hechanova, 2019), employee involvement climate (Naqshbandi, Tabche \& Choudhary, 2019) knowledge sharing (Kim \& Shim, 2018) knowledge search (Wang, Chen \& Chang, 2019) collaborative culture (Yang, Nguyen \& Le, 2018) knowledge process (Imran et al, 2018). This research aims to examine the influence of tacit and explicit knowledge towards innovation capability in packaging industry in order to welcome the industrial revolution 4.0. Previous researchers found prove regarding the positive and significant impact of tacit and explicit knowledge towards innovation capability (Ganguly et al, 2019; Aulawi, 2018; Rumanti et al, 2018 \& 2019; Torres \& Liang, 2016; Li et al, 2019). To be more specific, there are many researchers concluded that tacit knowledge positively and significantly impacts the innovation capability (Perez-Luno et al, 2018).

\section{METHODS}

\section{A. Definition of Operational Variable and Indicator}

Method that was used in this research is census survey method together with correlational research approach. Data collection is done by spreading questionnaire to every permanent employee in a particular company. Instrument that was used to measure the explicit knowledge sharing adapted by Liebowitz \& Chen (2001) dan Wang \& Wang (2012) using 6 items (EX1-EX6). Instrument that was used to measure the tacit 
knowledge is adapted by Holste \& Fields (2010), Lin (2006), and Wang \& Wang (2012) using 6 items (TC1 TC6). Innovation capability is measured by using 5 items (IC1-IC5) that is adapted by Lee \& Choi (2003). Questionnaire is closely designed except for questions/statements regarding respondent's identity, which is in a form of semi-opened questionnaire. Every items of closed questions/statements were given five answer options, which are strongly agree (SA) 5 points, agree (A) 4 points, neutral (N) 3 points, disagree (DA) 2 points, strongly disagree (SDA) 1 point. Method used in data preparation was by using PLS as well as software SmartPLS version 3.0 as the tool.

\section{B. Population and Sample}

Population in this research is the employee from one of the packaging industry in Indonesia, which has around 610 people. Questionnaire was spread by simple random sampling technique. Questionnaire results that were returned validly was 393 samples.

\section{RESULTS AND DISCUSSION}

\section{A. Sample Description}

Table 1. Descriptive Sample Information

\begin{tabular}{lccc}
\hline & Criteria & Total & \% \\
\hline Age & $<30$ years old & 88 & $22.4 \%$ \\
& $30-40$ years old & 166 & $42.2 \%$ \\
& $>40$ years old & 139 & $35.4 \%$ \\
\hline Years of Service & $<5$ years & 41 & $10.4 \%$ \\
& $5-10$ years & 232 & $59.1 \%$ \\
& $>10$ years & 120 & $30.5 \%$ \\
\hline Last Education & Bachelor & 41 & $10.4 \%$ \\
& Senior High/ College & 301 & $76.6 \%$ \\
& $\leq$ Junior High & 51 & $13.0 \%$ \\
\hline
\end{tabular}

\section{B. Validity Test Result and Research Reliability Indicator}

Stages on testing model of measuring involve convergent validity test, discriminant validity, and composite reliability. PLS analysis result could be used to test for research hypothesis if all indicators in PLS model has meet the requirements of convergent validity, discriminant validity and reliability test.

\section{Convergent Validity Testing}

Convergent validity test is done by seeing the value of loading factor of each indicators towards the construct. In most reference, with factor weighing from at least 0.5 is considered having validity that is strong enough to explain the latent construct (Chin, 1998; Ghozali, 2014; Hair et al., 2010). In this research, minimum limit of loading factor that is accepted is 0.5, with the condition of AVE score for every construct, which is $>0.5$ (Ghozali, 2014). 


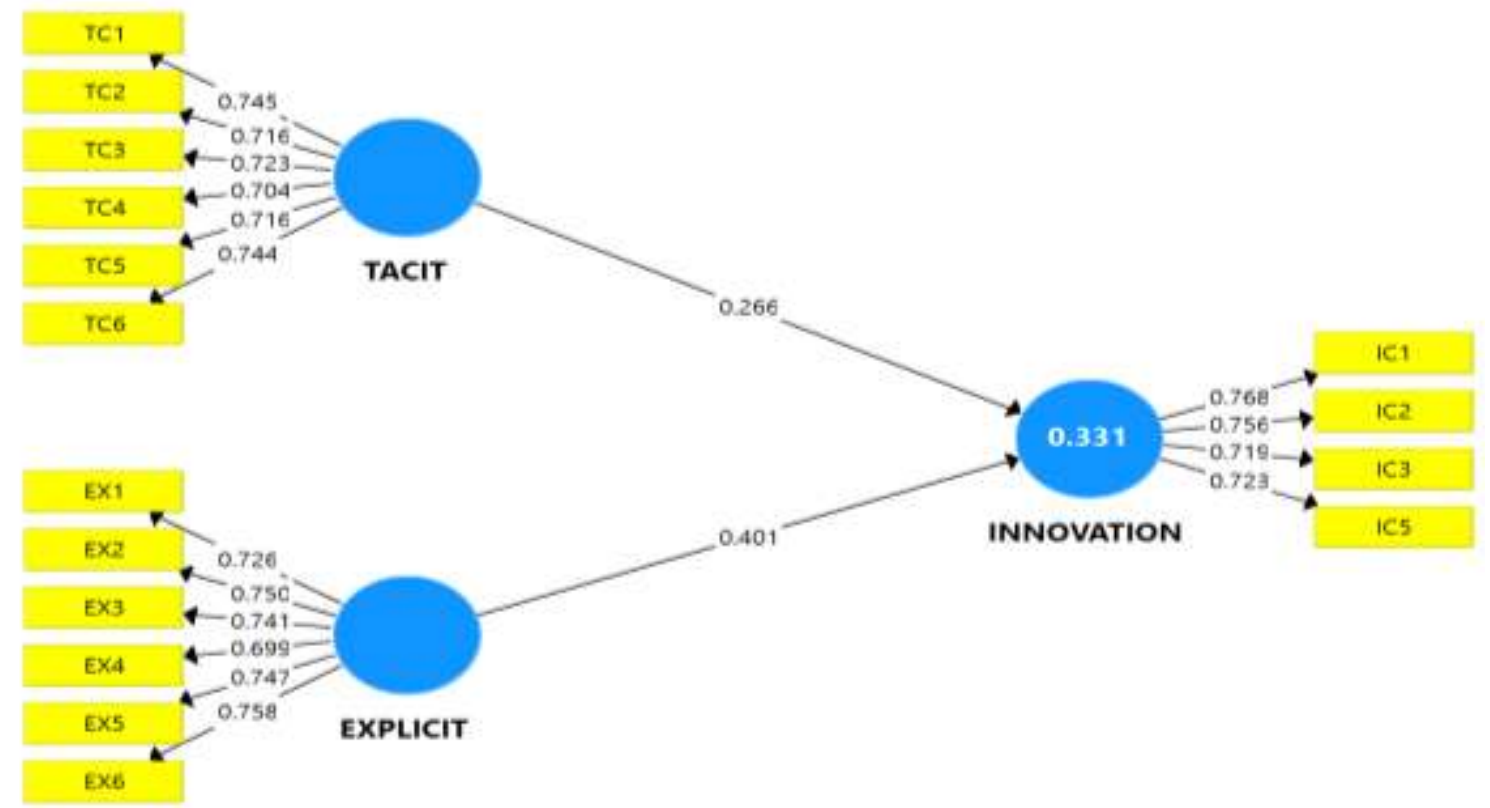

Figure 2. Validity Model Estimation

According to the result above, IC4 should be taken out since the score is below 0.5 and impacted the AVE to be below 0.5 as well. After IC4 is taken out, every indicator left has loading factor values and AVE above 0.5 , so the model has fully met the requirements of convergent validity. Therefore, other than seeing each of the indicator's loading factor value, convergent validity also being assessed from the AVE score in every construct. PLS Model is stated as fully meeting the convergent validity if the AVE score in every construct is $<0.5$ (Ghozali, 2014). AVE score in every construct is shown in the table below:

Table 2. Items Loadings, Composite Reliability, and Average Variance Extracted (AVE)

\begin{tabular}{|c|c|c|c|c|c|}
\hline Variables & Items & Loadings & $\begin{array}{c}\text { Cronbach's } \\
\text { Alpha }\end{array}$ & $\begin{array}{l}\text { Composite } \\
\text { Reliability }\end{array}$ & AVE \\
\hline \multirow[t]{6}{*}{ Tacit Knowledge (TACIT) } & TC1 & 0.745 & 0.819 & 0.869 & 0.525 \\
\hline & $\mathrm{TC} 2$ & 0.716 & & & \\
\hline & TC3 & 0.723 & & & \\
\hline & TC4 & 0.704 & & & \\
\hline & TC5 & 0.716 & & & \\
\hline & TC6 & 0.744 & & & \\
\hline \multirow{6}{*}{$\begin{array}{l}\text { Explicit Knowledge } \\
\text { (EXPLICIT) }\end{array}$} & EX1 & 0.726 & 0.832 & 0.877 & 0.543 \\
\hline & EX2 & 0.750 & & & \\
\hline & EX3 & 0.741 & & & \\
\hline & EX4 & 0.699 & & & \\
\hline & EX5 & 0.747 & & & \\
\hline & EX6 & 0.758 & & & \\
\hline \multirow{4}{*}{$\begin{array}{l}\text { Innovation capability } \\
\text { (INNOVATION) }\end{array}$} & IC1 & 0.768 & 0.727 & 0.869 & 0.525 \\
\hline & IC2 & 0.756 & & & \\
\hline & IC3 & 0.719 & & & \\
\hline & IC5 & 0.723 & & & \\
\hline
\end{tabular}




\section{Discriminant Validity Test}

Discriminant validity is done to ensure that every concept of each latent variables are in contrast with the other latent variables. A model has a good discriminant validity if the quadratic value of AVE in each exogeneous construct (value on the diagonal) exceeds the correlation between the construct with the other construct (value below diagonal) (Ghozali, 2014). Result of discriminant validity research is done by the quadratic value of AVE, which means by seeing the Fornell-Larcker Criterion Value that is obtained the same way as shown below:

Tabel 3. Discriminant Validity

\begin{tabular}{lccc}
\hline \multicolumn{1}{c}{ VARIABLES } & EXPLICIT & INNOVATION & TACIT \\
\hline EXPLICIT & $\mathbf{0 . 7 3 7}$ & $\mathbf{0 . 7 4 2}$ & \\
INNOVATION & 0.526 & 0.453 & $\mathbf{0 . 7 2 5}$ \\
TACIT & 0.467 & & \\
\hline
\end{tabular}

Discriminant validity test result shown in the Table 3 above indicates the whole construct having square root value of AVE above correlation value with the other latent construct (through Fornell-Larcker Criterion), so it can be concluded that a model has meet a discriminant validity.

\section{E. Construct Reliability Test}

Construct reliability can be assessed from the value of Cronbach's alpha and composite reliability from each construct. Value of composite reliability and Cronbach's alpha is suggested to be more than 0.7 (Ghozali, 2014). Reliability test result in the Table 2 above shows that all construct has composite reliability value and Cronbach's alpha value higher than $0.7(>0.7)$. In conclusion, all construct has met the reliability that is required.

\section{F. Hypothesis Examination}

Hypothesis test in PLS is also denoted as inner model test. This test covers significance test that has a direct and indirect impact as well as how large is the measurement of the exogenous variable impact towards the endogenous variable. To discover the effect of tacit and explicit knowledge sharing towards organizational learning and innovation capability, it needs a direct impact test. Direct impact test is done by using T-Statistic test in an analysis model called Partial Least Squared (PLS) with the help of SmartPLS 3.0 software. With the bootstrapping technique, $\mathrm{R}$ square value and significance test value can be obtained as shown in the table below:

Table 4. R Square Value

\begin{tabular}{ccc}
\hline & R Square & R Square Adjusted \\
\hline INNOVATION & 0.331 & 0.328 \\
\hline
\end{tabular}

Table 5. Hypotheses Testing

\begin{tabular}{cllcccc}
\hline Hypotheses & Relationship & Beta & SE & T Statistics & P-Values & Decision \\
\hline H1 & $\begin{array}{l}\text { EXPLICIT -> } \\
\text { INNOVATION }\end{array}$ & 0.401 & 0.047 & 8.566 & 0.000 & Supported \\
$\mathbf{H 2}$ & $\begin{array}{l}\text { TACIT -> } \\
\text { INNOVATION }\end{array}$ & 0.266 & 0.057 & 4.655 & 0.000 & Supported \\
\hline
\end{tabular}


According to the Table 4 above, R Square value for INNOVATION is 0.331 , which means that the innovation capability (IC) variable may be explained by the tacit knowledge (TC) variable and explicit knowledge (EX) that have a percentage of $33.1 \%$, while the rest $66.9 \%$ is explained by other variable that is not discussed in this research. Meanwhile, Table 5 showed T-statistics and P-Values which indicate the effect of the variables mentioned above.

\section{G. Discussion}

According to the research results, it can be concluded that explicit knowledge and tacit knowledge give positive and significant impact towards innovation capability. This means that the more positive the explicit and tacit knowledge done by the employees, the more conducive the individual innovation capability of the employees in the company. This research is parallel with the previous research done by Perez-Luno et al (2018), Terhorst et al (2018), Boadu et al (2018), Che et al (2019), as well as the conclusion made by Qi \& Chau (2018). This matter hinted that the rarest and the most valuable resource in the digital era is no longer an ordinary labor and mediocre, but an individual that is able to create an idea and new innovation (Xu, David \& Kim, 2018). With this reason, the scarcity of labor that has adequate and skilled tacit and explicit knowledge could immobilize innovation power, competitiveness, growth and flexibility of the company. There is no doubt that, in the future, talent and response of the individual in the process of knowledge sharing will represent the most important factor in a production. People with ideas and innovations will be the most valuable 'item' as the capital of competition. This research also concluded that a company could manage a past experience to be combined with tacit and explicit knowledge had by the employees nowadays. The point is that knowledge creation and knowledge management is related with this industrial performance era 4.0 .

\section{CONCLUSIONS AND SUGGESTIONS}

\section{A. Conclusions}

By adding the role of tacit knowledge as a predictor of innovation capability, an organization should give onotomy and the spaciousness to share to every of the employees. Therefore, organization needs to create an organization's environment as positive environment that spur competency and engagement of the employees in the company. In fact, knowledge management will flow effectively in the company if the individual performance of the employees is proper (Manaf et al, 2017).

Every researcher keeps learning about the knowledge as an important organization's resource and can be mentioned as knowledge transfer, both tacit or explicit knowledge could improve the organization's performance significantly (Thomas, 2019). Organizational learning changes the individual's knowledge to organization's knowledge. This research concluded that organizational learning has a role as a catalyst of the knowledge sharing process between the packaging employees.

\section{B. Managerial Implications}

Based on the conclusion of this research, the company's management of packaging industry needs to build a maximum involvement of every employee to do knowledge sharing, which can be in a form of either tacit or explicit knowledge. SECI Model can be used to carry out this process. Employee's practices in every division of organization is referred as an essential with the level of intensity, content, and context that are corresponded with the key performance indicator of each employees.

The process of sharing knowledge to build innovation capability of a company is unlimited in the process of internal organization. However, management should widen the process of building this innovation through absorbing, articulating, utilizing and managing the knowledge that is sourced from external partners, such as customer, contractor, supplier, university and educational institution, as well as industrial society in a large scale. Management could activate learning from others when giving an employee a task to visit a supplier, customer, university, or even other strategic partners. This is because of the external knowledge, such as the one originated from the supplier, client, contractor, and consultant that are supporting the power of innovation capability of a company (Simao \& Franco, 2018). 


\section{Limitation}

This research has a number of limitations. Firstly, this research analyzed about the influence of tacit and explicit knowledge towards innovation capability, there are may be a few of other variables influencing innovation capability, such as leadership, organizational environment, employee's commitment, etc. The author highly recommends to search, explore, and analyze. Secondly, this research is done in packaging industry and may be unable to be generalized to other industries. Therefore, it is recommended to do a further research regarding this topic in other industries.

\section{REFERENCES}

[1] Addis, M. (2016) Tacit and explicit knowledge in construction management, Construction Management and Economics, 34:7-8, 439-445, DOI: 10.1080/01446193.2016.1180416

[2] Afsar, B., Masood, M., \& Umrani, W. A. (2019). The role of job crafting and knowledge sharing on the effect of transformational leadership on innovative work behavior. Personnel Review. doi:10.1108/pr-04-2018-0133

[3] Agistiawati, E., Asbari, M., Basuki, S., Yuwono, T., \& Chidir, G. (2020). Exploring the Impact of Knowledge Sharing and Organizational Culture on Teacher Innovation Capability. International Journal of Science and Management Studies (IJSMS), 3(3), 62-77. http://www.ijsmsjournal.org/volume3-issue3.html

[4] Agyemang, F. G., \& Boateng, H. (2019). Tacit knowledge transfer from a master to an apprentice among hairdressers. Education + Training, 61(1), 108-120. doi:10.1108/et-12-2017-0200

[5] Asbari, M., Santoso, P., \& Purwanto, A. (2019). Pengaruh kepemimpinan dan budaya organisasi terhadap perilaku kerja inovatif pada industri 4.0. JIM UPB (Jurnal Ilmiah Manajemen Universitas Putera Batam), 8(1), 7-15. doi:10.33884/jimupb.v8i1.1562

[6] Asbari, M., Santoso, P., and Purwanto, A. (2019). Influence of Leadership, Motivation, Competence, Commitment and Culture on ISO 9001:2015 Performance in Packaging Industry, Scholars Journal of Economics, Business and Management, 6(12): 577-582. DOI: 10.36347/sjebm.2019.v06i12.005

[7] Asher, D., \& Popper, M. (2019). Tacit knowledge as a multilayer phenomenon: the "onion" model. The Learning Organization. doi:10.1108/tlo-06-2018-0105

[8] Attia, A. and Salama, I. (2018), "Knowledge management capability and supply chain management practices in the Saudi food industry", Business Process Management Journal, Vol. 24 No. 2, pp. 459-477. https://doi.org/10.1108/BPMJ-01-2017-0001

[9] Aulawi, H. (2018). Improving Innovation capability Trough Creativity and Knowledge Sharing Behavior. IOP Conference Series: Materials Science and Engineering, 434, 012242. doi:10.1088/1757-899x/434/1/012242

[10] Baldé, M., Ferreira, A. and Maynard, T. (2018), "SECI driven creativity: the role of team trust and intrinsic motivation", Journal of Knowledge Management, Vol. 22 No. 8, pp. 1688-1711. https://doi.org/10.1108/JKM-06-2017-0241

[11] Bashir, M. and Farooq, R. (2019), "The synergetic effect of knowledge management and business model innovation on firm competence: A systematic review", International Journal of Innovation Science, Vol. 11 No. 3, pp. $362-387$. https://doi.org/10.1108/IJIS-10-2018-0103

[12] Boadu, F., Xie, Y., Du, Y.-F., \& Dwomo-Fokuo, E. (2018). MNEs Subsidiary Training and Development and Firm Innovative Performance: The Moderating Effects of Tacit and Explicit Knowledge Received from Headquarters. Sustainability, 10(11), 4208. doi:10.3390/su10114208

[13] Borges, R., Bernardi, M. and Petrin, R. (2019), "Cross-country findings on tacit knowledge sharing: evidence from the Brazilian and Indonesian IT workers", Journal of Knowledge Management, Vol. 23 No. 4, pp. 742-762. https://doi.org/10.1108/JKM-042018-0234

[14] Borrego, G., Morán, A. L., Palacio, R. R., Vizcaíno, A., \& García, F. O. (2019). Towards a reduction in architectural knowledge vaporization during agile global software development. Information and Software Technology. doi:10.1016/j.infsof.2019.04.008

[15] Boske, C. and Osanloo, A. (2015), "Conclusion - Preparing all School Community Leaders to Live their Work", Living the Work: Promoting Social Justice and Equity Work in Schools around the World (Advances in Educational Administration, Vol. 23), Emerald Group Publishing Limited, pp. 405-426. https://doi.org/10.1108/S1479-366020140000023032

[16] Cairó Battistutti, O. \& Bork, D. Cogn Process (2017) 18: 461. https://doi.org/10.1007/s10339-017-0825-6

[17] Cantwell, J. and Zaman, S. (2018), "Connecting local and global technological knowledge sourcing", Competitiveness Review, Vol. 28 No. 3, pp. 277-294. https://doi.org/10.1108/CR-08-2017-0044 
[18] Castela, B., Ferreira, F., Ferreira, J. and Marques, C. (2018), "Assessing the innovation capability of small- and medium-sized enterprises using a non-parametric and integrative approach", Management Decision, Vol. 56 No. 6, pp. $1365-1383$. https://doi.org/10.1108/MD-02-2017-0156

[19] Chang, C. and Lin, T. (2015), "The role of organizational culture in the knowledge management process", Journal of Knowledge Management, Vol. 19 No. 3, pp. 433-455. https://doi.org/10.1108/JKM-08-2014-0353

[20] Chatterjee, A., Pereira, A. and Sarkar, B. (2018), "Learning transfer system inventory (LTSI) and knowledge creation in organizations", The Learning Organization, Vol. 25 No. 5, pp. 305-319. https://doi.org/10.1108/TLO-06-2016-0039

[21] Che, T., Wu, Z., Wang, Y. and Yang, R. (2019), "Impacts of knowledge sourcing on employee innovation: the moderating effect of information transparency", Journal of Knowledge Management, Vol. 23 No. 2, pp. 221-239. https://doi.org/10.1108/JKM-11-20170554

[22] Che, T., Wu, Z., Wang, Y., \& Yang, R. (2018). Impacts of knowledge sourcing on employee innovation: the moderating effect of information transparency. Journal of Knowledge Management. doi:10.1108/jkm-11-2017-0554

[23] Chen, H., Baptista Nunes, M., Ragsdell, G., \& An, X. (2018). Extrinsic and intrinsic motivation for experience grounded tacit knowledge sharing in Chinese software organisations. Journal of Knowledge Management, 22(2), 478-498. doi:10.1108/jkm-032017-0101

[24] Chin, WW. (1998). The Partial Least Squares Approach to Structural Equation Modeling. Modern Methods for Business Research, In: G. A. Marcoulides, Ed., Lawrence Erlbaum Associates Publisher, New Jersey, pp. 295-336.

[25] Cifariello, P., Ferragina, P., \& Ponza, M. (2019). Wiser: A semantic approach for expert finding in academia based on entity linking. Information Systems, 82, 1-16. doi:10.1016/j.is.2018.12.003

[26] Culot, G., Orzes, G., \& Sartor, M. (2019). Integration and scale in the context of Industry 4.0: the evolving shapes of manufacturing value chains. IEEE Engineering Management Review, 1-1. doi:10.1109/emr.2019.2900652

[27] Darwish, T. K., Zeng, J., Rezaei Zadeh, M., \& Haak-Saheem, W. (2018). Organizational learning of Absorptive Capacity and Innovation: Does Leadership Matter? European Management Review. doi:10.1111/emre.12320

[28] DeranEX, K., McLeod, A., \& Schmidt, E. (2017). ERP Simulation Effects on Knowledge and Attitudes of Experienced Users. Journal of Computer Information Systems, 1-11. doi:10.1080/08874417.2017.1373610

[29] Durana, Kral, Stehel, Lazaroiu, \& Sroka. (2019). Quality Culture of Manufacturing Enterprises: A Possible Way to Adaptation to Industry 4.0. Social Sciences, 8(4), 124. doi:10.3390/socsci8040124

[30] Ferraris, A., Santoro, G. and Scuotto, V. (2018), "Dual relational embeddedness and knowledge transfer in European multinational corporations and subsidiaries", Journal of Knowledge Management, Vol. ahead-of-print No. ahead-of-print. https://doi.org/10.1108/JKM-09-2017-0407

[31] Ferreira, J., Mueller, J. and Papa, A. (2018), "Strategic knowledge management: theory, practice and future challenges", Journal of Knowledge Management, Vol. ahead-of-print No. ahead-of-print. https://doi.org/10.1108/JKM-07-2018-0461

[32] Ganguly, A., Talukdar, A. and Chatterjee, D. (2019), "Evaluating the role of social capital, tacit knowledge sharing, knowledge quality and reciprocity in determining innovation capability of an organization", Journal of Knowledge Management, Vol. 23 No. 6 , pp. 1105-1135. https://doi.org/10.1108/JKM-03-2018-0190

[33] Ghozali, I. Structural Equation Modeling, Metode Alternatif dengan Partial Least Square (PLS), Edisi 4. Semarang: Badan Penerbit Universitas Diponegoro. 2014.

[34] GunasEXaran, A., Subramanian, N., \& Ngai, E. (2018). Quality Management in the 21st Century Enterprises: Research pathway towards Industry 4.0. International Journal of Production Economics. doi:10.1016/j.ijpe.2018.09.005

[35] Guo, Y., Jasovska, P., Rammal, H. and Rose, E. (2018), "Global mobility of professionals and the transfer of tacit knowledge in multinational service firms", Journal of Knowledge Management, Vol. ahead-of-print No. ahead-of-print. https://doi.org/10.1108/JKM-09-2017-0399

[36] Haamann, T., \& Basten, D. (2018). The role of information technology in bridging the knowing-doing gap: an exploratory case study on knowledge application. Journal of Knowledge Management. doi:10.1108/jkm-01-2018-0030

[37] Hair, J. F., Black. W. C., Babin. B. J.; and Anderson. R. E. (2010), Multivariate Data Analysis, 7th ed. New Jersey: Pearson Prentice Hall.

[38] Hamada, T. (2019). Determinants of Decision-Makers' Attitudes toward Industry 4.0 Adaptation. Social Sciences, 8(5), 140. doi:10.3390/socsci8050140 
[39] Hartley, J. (2018), "Ten propositions about public leadership", International Journal of Public Leadership, Vol. 14 No. 4, pp. 202217. https://doi.org/10.1108/IJPL-09-2018-0048

[40] Haseeb, M., Hussain, H. I., Ślusarczyk, B., \& Jermsittiparsert, K. (2019). Industry 4.0: A Solution towards Technology Challenges of Sustainable Business Performance. Social Sciences, 8(5), 154. doi:10.3390/socsci8050154

[41] Hodgins, M. and Dadich, A. (2017), "Positive emotion in knowledge creation", Journal of Health Organization and Management, Vol. 31 No. 2, pp. 162-174. https://doi.org/10.1108/JHOM-06-2016-0108

[42] Holford, W.D. (2018). The future of human creative knowledge work within the digital economy. Futures. doi:10.1016/j.futures.2018.10.002

[43] Holste, J. S., \& Fields, D. (2010). Trust and tacit knowledge sharing and use. Journal of Knowledge Management, 14(1), 128-140. doi:10.1108/13673271011015615

[44] Huang, F., Gardner, S. and Moayer, S. (2016), "Towards a framework for strategic knowledge management practice: Integrating soft and hard systems for competitive advantage", VINE Journal of Information and Knowledge Management Systems, Vol. 46 No. 4, pp. 492-507. https://doi.org/10.1108/VJIKMS-08-2015-0049

[45] Huesig, S. and Endres, H. (2019), "Exploring the digital innovation process: The role of functionality for the adoption of innovation management software by innovation managers", European Journal of Innovation Management, Vol. 22 No. 2, pp. $302-314$. https://doi.org/10.1108/EJIM-02-2018-0051

[46] Hussain, S. T., Lei, S., Akram, T., Haider, M. J., Hussain, S. H., \& Ali, M. (2018). Kurt Lewin's change model: A critical review of the role of leadership and employee involvement in organizational change. Journal of Innovation \& Knowledge, 3(3), 123-127. doi:10.1016/j.jik.2016.07.002

[47] Imran, M., Ilyas, M., Aslam, U. and Fatima, T. (2018), "Knowledge processes and firm performance: the mediating effect of employee creativity", Journal of Organizational Change Management, Vol. 31 No. 3, pp. 512-531. https://doi.org/10.1108/JOCM10-2016-0202

[48] Jakhar, S. K., Mangla, S. K., Luthra, S., \& Kusi-Sarpong, S. (2018). When stakeholder pressure drives the circular economy. Management Decision. doi:10.1108/md-09-2018-0990

[49] Jaleel, S. and Verghis, A.M. (2015). Knowledge Creation in Constructivist Learning. Universal Journal of Educational Research 3(1): 8-12. doi: 10.13189/ujer.2015.030102.

[50] Jiménez-Jiménez, D., \& Sanz-Valle, R. (2011). Innovation, organizational learning, and performance. Journal of Business Research, 64(4), 408-417. doi:10.1016/j.jbusres.2010.09.010

[51] Jou, M. Lin, Y. and Wu, D. (2016) Effect of a blended learning environment on student critical thinking and knowledge transformation, Interactive Learning Environments, 24:6, 1131-1147, DOI: 10.1080/10494820.2014.961485

[52] Kasim, A., EXinci, Y., Altinay, L. and Hussain, K. (2018) Impact of market orientation, organizational learning and market conditions on small and medium-size hospitality enterprises, Journal of Hospitality Marketing \& Management, 27:7, 855-875, DOI: $10.1080 / 19368623.2018 .1438955$

[53] Kawamura, K. (2016), "Kristine Marin Kawamura, PhD interviews Ikujiro Nonaka, PhD", Cross Cultural \& Strategic Management, Vol. 23 No. 4, pp. 613-632. https://doi.org/10.1108/CCSM-06-2014-0056

[54] Khoshsorour, A., Gilaninia, S. 2018. Kuwait Chapter of the Arabian. Journal of Business and Management Review; Kuwait City 7(3): 1-4. doi: 10.12816/0048627

[55] Kim, N. and Shim, C. (2018), "Social capital, knowledge sharing and innovation of small- and medium-sized enterprises in a tourism cluster", International Journal of Contemporary Hospitality Management, Vol. 30 No. 6, pp. $2417-2437$. https://doi.org/10.1108/IJCHM-07-2016-0392

[56] Lee, J.-C., Shiue, Y.-C., \& Chen, C.-Y. (2016). Examining the impacts of organizational culture and top management support of knowledge sharing on the success of software process improvement. Computers in Human Behavior, 54, 462-474. doi:10.1016/j.chb.2015.08.030

[57] Lee, Peter. (2019). Tacit Knowledge and University-Industry Technology Transfer. Research Handbook on Intellectual Property and Technology Transfer (2019, Forthcoming); UC Davis Legal Studies Research Paper Forthcoming. doi: http://dx.doi.org/10.2139/ssrn.3417933

[58] Li, M., Liu, H. and Zhou, J. (2018), "G-SECI model-based knowledge creation for CoPS innovation: the role of grey knowledge", Journal of Knowledge Management, Vol. 22 No. 4, pp. 887-911. https://doi.org/10.1108/JKM-10-2016-0458 
[59] Li, Song, Wang, \& Li. (2019). Intellectual Capital, Knowledge Sharing, and Innovation Performance: Evidence from the Chinese Construction Industry. Sustainability, 11(9), 2713. doi:10.3390/su11092713

[60] Liebowitz, J. and Chen, Y. 2001. Developing knowledge-sharing proficiencies. Knowledge Management Review 3(6): 12-15. https://www.researchgate.net/publication/_285908349_Developing_knowledge-sharing_proficiencies_Building_a_supportive_ culture_for_knowledge-sharing

[61] Lievre, P. and Tang, J. (2015), "SECI and inter-organizational and intercultural knowledge transfer: a case-study of controversies around a project of co-operation between France and China in the health sector", Journal of Knowledge Management, Vol. 19 No. 5, pp. 1069-1086. https://doi.org/10.1108/JKM-02-2015-0054

[62] Lin, C.-P. (2006). To Share or Not to Share: Modeling Tacit Knowledge Sharing, Its Mediators and Antecedents. Journal of Business Ethics, 70(4), 411-428. doi:10.1007/s10551-006-9119-0

[63] Lin, H., Lee, Y. (2017). A Study of The Influence of Organizational learning on Employees' Innovative Behavior and Work Engagement by A Cross-Level Examination. Eurasia Journal of Mathematics, Science and Technology Education, 13(7), 34633478. https://doi.org/10.12973/eurasia.2017.00738a

[64] Lombardi, R. (2019). Knowledge transfer and organizational performance and business process: past, present and future researches. Business Process Management Journal, 25(1), 2-9. doi:10.1108/bpmj-02-2019-368

[65] Lund, H. B., \& Karlsen, A. (2019). The importance of vocational education institutions in manufacturing regions: adding content to a broad definition of regional innovation systems. Industry and Innovation, 1-20. doi:10.1080/13662716.2019.1616534

[66] Ma, Q., Mayfield, M. and Mayfield, J. (2018), "Keep them on-board! How organizations can develop employee embeddedness to increase employee retention", Development and Learning in Organizations, Vol. 32 No. 4, pp. 5-9. https://doi.org/10.1108/DLO11-2017-0094

[67] Malik, A. (2019). Creating competitive advantage through source basic capital strategic humanity in the industrial age 4.0. International Research Journal of Advanced Engineering and Science 4(1): 209-215. www.irjaes.com/pdf/V4N1Y18IRJAES/IRJAES-V4N1P195Y19.pdf

[68] Manaf, H. A., Armstrong, S. J., Lawton, A., \& Harvey, W. S. (2017). Managerial Tacit Knowledge, Individual Performance, and the Moderating Role of Employee Personality. International Journal of Public Administration, $1-13$. doi:10.1080/01900692.2017.1386676

[69] Mohajan, Haradhan (2016): Sharing of Tacit Knowledge in Organizations: A Review. Published in: American Journal of Computer Science and Engineering, Vol. 3, No. 2 (1 July 2016): pp. 6-19. https://mpra.ub.uni-muenchen.de/id/eprint/82958

[70] Muñoz, C.A., Mosey, S. and Binks, M. (2015) The tacit mystery: reconciling different approaches to tacit knowledge. Knowledge Management Research \& Practice, 13:3, 289-298, DOI: 10.1057/kmrp.2013.50

[71] Muscio, A., \& Ciffolilli, A. (2019). What drives the capacity to integrate Industry 4.0 technologies? Evidence from European R\&D projects. Economics of Innovation and New Technology, 1-15. doi:10.1080/10438599.2019.1597413

[72] Muthuveloo, R., Shanmugam, N., \& Teoh, A. P. (2017). The impact of tacit knowledge management on organizational performance: Evidence from Malaysia. Asia Pacific Management Review, 22(4), 192-201. doi:10.1016/j.apmrv.2017.07.010

[73] Naqshbandi, M., Tabche, I. and Choudhary, N. (2019), Managing open innovation: The roles of empowering leadership and employee involvement climate, Management Decision, Vol. 57 No. 3, pp. 703-723. https://doi.org/10.1108/MD-07-2017-0660

[74] Nonaka I., Hirose Nishihara A. (2018) Introduction to the Concepts and Frameworks of Knowledge-Creating Theory. In: Hirose Nishihara A., Matsunaga M., Nonaka I., Yokomichi K. (eds) Knowledge Creation in Community Development. Palgrave Macmillan, Cham. https://doi.org/10.1007/978-3-319-57481-3_1

[75] Nonaka I., Toyama R. (2015) The Knowledge-creating Theory Revisited: Knowledge Creation as a Synthesizing Process. In: Edwards J.S. (eds) The Essentials of Knowledge Management. OR Essentials Series. Palgrave Macmillan, London. https://doi.org/10.1057/9781137552105_4

[76] Norwich, B., Koutsouris, G., Fujita, T., Ralph, T., Adlam, A. and Milton, F. (2016), "Exploring knowledge bridging and translation in lesson study using an inter-professional team", International Journal for Lesson and Learning Studies, Vol. 5 No. 3, pp. 180-195. https://doi.org/10.1108/IJLLS-02-2016-0006

[77] Okuyama, R. (2017), "Importance of tacit knowledge in incremental innovation: Implications from drug discovery cases", Journal of Strategy and Management, Vol. 10 No. 1, pp. 118-130. https://doi.org/10.1108/JSMA-02-2016-0016

[78] Parida, V., Sjödin, D., \& Reim, W. (2019). Reviewing Literature on Digitalization, Business Model Innovation, and Sustainable Industry: Past Achievements and Future Promises. Sustainability, 11(2), 391. doi:10.3390/su11020391 
[79] Pérez-Fuillerat, N., Solano-Ruiz, M. C., \& Amezcua, M. (2018). Conocimiento tácito: características en la práctica enfermera. Gaceta Sanitaria. doi:10.1016/j.gaceta.2017.11.002

[80] Pérez-Luño, A., Alegre, J., \& Valle-Cabrera, R. (2018). The role of tacit knowledge in connecting knowledge exchange and combination with innovation. Technology Analysis \& Strategic Management, 1-13. doi:10.1080/09537325.2018.1492712

[81] Pérez-Luño, A., Alegre, J., \& Valle-Cabrera, R. (2018). The role of tacit knowledge in connecting knowledge exchange and combination with innovation. Technology Analysis \& Strategic Management, 1-13. doi:10.1080/09537325.2018.1492712

[82] Polanyi, M. (1966). The Tacit dimension. New York: Doubleday \& Co.

[83] Prasarnphanich, P., Janz, B. and Patel, J. (2016), "Towards a better understanding of system analysts' tacit knowledge: A mixed method approach", Information Technology \& People, Vol. 29 No. 1, pp. 69-98. https://doi.org/10.1108/ITP-06-2014-0123

[84] Putra, A. S., Novitasari, D., Asbari, M., Purwanto, A., Iskandar, J., Hutagalung, D., \& Cahyono, Y. (2020). Examine Relationship of Soft Skills, Hard Skills, Innovation and Performance: the Mediation Effect of Organizational Learning. International Journal of Science and Management Studies (IJSMS), 3(3), 27-43. http://www.ijsmsjournal.org/2020/volume-3 issue-3/ijsms-v3i3p104.pdf

[85] Qi, C. and Chau, P.Y.K. (2018) Will enterprise social networking systems promote knowledge management and organizational learning? An empirical study, Journal of Organizational Computing and Electronic Commerce, 28:1, 31-57, DOI: $10.1080 / 10919392.2018 .1407081$

[86] Razmerita L., Phillips-Wren G., Jain L.C. (2016) Advances in Knowledge Management: An Overview. In: Razmerita L., PhillipsWren G., Jain L. (eds) Innovations in Knowledge Management. Intelligent Systems Reference Library, vol 95. Springer, Berlin, Heidelberg. https://doi.org/10.1007/978-3-662-47827-1_1

[87] Rothberg, H. and Erickson, G. (2017), "Big data systems: knowledge transfer or intelligence insights?", Journal of Knowledge Management, Vol. 21 No. 1, pp. 92-112. https://doi.org/10.1108/JKM-07-2015-0300

[88] Ruiz-Torres, A., Cardoza, G., Kuula, M., Oliver, Y. and Rosa-Polanco, H. (2018), "Logistic services in the Caribbean region: An analysis of collaboration, innovation capabilities and process improvement", Academia Revista Latinoamericana de Administración, Vol. 31 No. 3, pp. 534-552. https://doi.org/10.1108/ARLA-03-2017-0078

[89] Rumanti, A. A., Samadhi, T. M. A. A., Wiratmadja, I. I., \& Sunaryo, I. (2018). A systematic literature review on knowledge sharing for innovation: Empirical study approach. 5th International Conference on Industrial Engineering and Applications (ICIEA). doi:10.1109/iea.2018.8387153

[90] Rumanti, A. A., Wiratmadja, I. I., Sunaryo, I., Ajidarma, P., \& Ari Samadhi, T. M. A. (2019). Firm Innovation capability through Knowledge Sharing at Indonesian Small and Medium Industries: Impact of Tacit and Explicit Knowledge Perspective. 2019 IEEE 6th International Conference on Industrial Engineering and Applications (ICIEA). doi:10.1109/iea.2019.8714947

[91] Samsir, S. (2018), The effect of leadership orientation on innovation and its relationship with competitive advantages of small and medium enterprises in Indonesia, International Journal of Law and Management, Vol. 60 No. 2 , pp. 530-542. https://doi.org/10.1108/IJLMA-01-2017-0005

[92] Santoro, G., Vrontis, D., Thrassou, A., \& Dezi, L. (2017). The Internet of Things: Building a knowledge management system for open innovation and knowledge management capacity. Technological Forecasting and Social Change. doi:10.1016/j.techfore.2017.02.034

[93] Sasaki, Y. (2017), "A note on systems intelligence in knowledge management", The Learning Organization, Vol. 24 No. 4, pp. 236244. https://doi.org/10.1108/TLO-09-2016-0062

[94] Schuckert, M., Kim, T., PaEX, S. and Lee, G. (2018), "Motivate to innovate: How authentic and transformational leaders influence employees' psychological capital and service innovation behavior", International Journal of Contemporary Hospitality Management, Vol. 30 No. 2, pp. 776-796. https://doi.org/10.1108/IJCHM-05-2016-0282

[95] Serna M., E., Bachiller S., O., \& Serna A., A. (2017). Knowledge meaning and management in requirements engineering. International Journal of Information Management, 37(3), 155-161. doi:10.1016/j.ijinfomgt.2017.01.005

[96] Simao, L. and Franco, M. (2018), "External knowledge sources as antecedents of organizational innovation in firm workplaces: a knowledge-based perspective", Journal of Knowledge Management, Vol. 22 No. 2, pp. 237-256. https://doi.org/10.1108/JKM-012017-0002

[97] Sousa, M. J., \& Rocha, Á. (2019). Strategic Knowledge Management in the Digital Age. Journal of Business Research, 94, 223226. doi:10.1016/j.jbusres.2018.10.016

[98] Spraggon, M. and Bodolica, V. (2017), "Collective tacit knowledge generation through play: Integrating socially distributed cognition and transactive memory systems", Management Decision, Vol. 55 No. 1, pp. 119-135. https://doi.org/10.1108/MD-052015-0173 
[99] Stachová, K., Papula, J., Stacho, Z., \& Kohnová, L. (2019). External Partnerships in Employee Education and Development as the Key to Facing Industry 4.0 Challenges. Sustainability, 11(2), 345. doi:10.3390/su11020345

[100] Stanica, S. and Peydro, J. (2016), "How does the employee cross-training lean tool affect the knowledge transfer in product development processes?", VINE Journal of Information and Knowledge Management Systems, Vol. 46 No. 3, pp. $371-385$. https://doi.org/10.1108/VJIKMS-11-2015-0061

[101] Stewart, C., Schiavon, L.M. and Bellotto, M.L. (2017) Knowledge, nutrition and coaching pedagogy: a perspective from female Brazilian Olympic gymnasts, Sport, Education and Society, 22(4): 511-527, DOI: 10.1080/13573322.2015.1046428

[102] SwierczEX, A. (2019), "Manufacturer structural embeddedness and the network rent: the intervening role of relational embeddedness in the triadic supply chains", Supply Chain Management, Vol. 24 No. 3, pp. 334-354. https://doi.org/10.1108/SCM06-2018-0232

[103] Tang, V., Yanine, F. and Valenzuela, L. (2016), "Data, information, knowledge and intelligence: The mega-nano hypothesis and its implications in innovation", International Journal of Innovation Science, Vol. 8 No. 3, pp. 199-216. https://doi.org/10.1108/IJIS-072016-0022

[104] Terhorst, A., Lusher, D., Bolton, D., Elsum, I., \& Wang, P. (2018). Tacit Knowledge Sharing in Open Innovation Projects. Project Management Journal, 49(4), 5-19. doi:10.1177/8756972818781628

[105] Thomas, N. (2019), "Two aspects of knowledge transfer: what every manager should know about using analogy and narrative", Development and Learning in Organizations, Vol. 33 No. 1, pp. 12-15. https://doi.org/10.1108/DLO-04-2018-0046

[106] Torres, O. J. J., \& Liang, D. (2016). Knowledge Sharing and the Innovation capability of Chinese Firms: The Role of Guanxi. 2016 International Conference on Industrial Engineering, Management Science and Application (ICIMSA). doi:10.1109/icimsa.2016.7504015

[107] Tsai, F. and Hsu, I. (2019), "The effects of social capital on knowledge heterogeneity", Management Decision, Vol. 57 No. 5, pp. 1237-1253. https://doi.org/10.1108/MD-12-2016-0909

[108] Villaluz, V. and Hechanova, M. (2019), "Ownership and leadership in building an innovation culture", Leadership \& Organization Development Journal, Vol. 40 No. 2, pp. 138-150. https://doi.org/10.1108/LODJ-05-2018-0184

[109] Wang, C., Chen, M. and Chang, C. (2019), "The double-edged effect of knowledge search on innovation generations", European Journal of Innovation Management, Vol. ahead-of-print No. ahead-of-print. https://doi.org/10.1108/EJIM-04-2018-0072

[110] Wang, J., \& Liu, L. (2019). Study on the mechanism of customers' participation in knowledge sharing. Expert Systems, e12367. doi:10.1111/exsy. 12367

[111] Wang, X., Arnett, D. and Hou, L. (2016), "Using external knowledge to improve organizational innovativeness: understanding the knowledge leveraging process", Journal of Business \& Industrial Marketing, Vol. 31 No. 2 , pp. $164-173$. https://doi.org/10.1108/JBIM-04-2014-0064

[112] Wang, Z., \& Wang, N. (2012). Knowledge sharing, innovation and firm performance. Expert Systems with Applications, 39(10), 8899-8908. doi:10.1016/j.eswa.2012.02.017

[113] Wójcik, M., Jeziorska-Biel, P., \& Czapiewski, K. (2019). Between words: A generational discussion about farming knowledge sources. Journal of Rural Studies, 67, 130-141. doi:10.1016/j.jrurstud.2019.02.024

[114] Xu, M., David, J. M., \& Kim, S. H. (2018). The Fourth Industrial Revolution: Opportunities and Challenges. International Journal of Financial Research, 9(2), 90. doi:10.5430/ijfr.v9n2p90

[115] Yang, Z., Nguyen, V. and Le, P. (2018), Knowledge sharing serves as a mediator between collaborative culture and innovation capability: an empirical research, Journal of Business \& Industrial Marketing, Vol. 33 No. 7, pp. 958-969. https://doi.org/10.1108/JBIM-10-2017-0245

[116] Zambon, I., Cecchini, M., Egidi, G., Saporito, M. G., \& Colantoni, A. (2019). Revolution 4.0: Industry vs. Agriculture in a Future Development for SMEs. Processes, 7(1), 36. doi:10.3390/pr7010036

[117] Zebal, M., Ferdous, A., \& Chambers, C. (2019). An integrated model of marketing knowledge - a tacit knowledge perspective. Journal of Research in Marketing and Entrepreneurship. doi:10.1108/jrme-03-2018-0018

[118] Zhang, C., Xiao, H., Gursoy, D. and Rao, Y. (2015). Tacit knowledge spillover and sustainability in destination development. Journal of Sustainable Tourism, 23:7, 1029-1048, DOI: 10.1080/09669582.2015.1032299

[119] Zouaghi, F., Sánchez, M., \& Martínez, M. G. (2018). Did the global financial crisis impact firms' innovation performance? The role of internal and external knowledge capabilities in high and low tech industries. Technological Forecasting and Social Change, 132, 92-104. doi:10.1016/j.techfore.2018.01.011 